\title{
Bone sialoprotein plays a functional role in bone formation and osteoclastogenesis
}

\author{
Luc Malaval, ${ }^{1}$ Ndéyé Marième Wade-Guéye, ${ }^{1}$ Maya Boudiffa, ${ }^{1}$ Jia Fei, ${ }^{1}$ \\ Ralph Zirngibl, ${ }^{6}$ Frieda Chen, ${ }^{6}$ Norbert Laroche, ${ }^{1}$ Jean-Paul Roux, ${ }^{2}$ \\ Brigitte Burt-Pichat, ${ }^{2}$ François Duboeuf, ${ }^{2}$ Georges Boivin, ${ }^{2}$ Pierre Jurdic, ${ }^{3}$ \\ Marie-Hélène Lafage-Proust, ${ }^{1}$ Joëlle Amédée, ${ }^{4}$ Laurence Vico, ${ }^{1}$ \\ Janet Rossant, ${ }^{5,6}$ and Jane E. Aubin ${ }^{6}$
}

\begin{abstract}
'Institut National de la Santé et de la Recherche Médicale U890, IFR 143, Université Jean-Monnet, Saint-Etienne, F42023, France

${ }^{2}$ Institut National de la Santé et de la Recherche Médicale U831, IFR 62, Université de Lyon, Lyon, F69008, France ${ }^{3}$ Institut de Génomique Fonctionnelle de Lyon, Institut Fédératif Biosciences Gerland Lyon Sud, Université Lyon 1, Centre National de la Recherche Scientifique, INRA, Ecole Normale Supérieure, F69364 Lyon, France ${ }^{4}$ Institut National de la Santé et de la Recherche Médicale U577, Université Victor Segalen, Bordeaux, F33076, France ${ }_{5}^{5}$ Program in Developmental and Stem Cell Biology, Hospital for Sick Children, Toronto, Ontario MG5 1X8, Canada ${ }^{6}$ Department of Molecular Genetics, University of Toronto, Toronto, Ontario M5S 1A8, Canada
\end{abstract}

Bone sialoprotein (BSP) and osteopontin (OPN) are both highly expressed in bone, but their functional specificities are unknown. OPN knockout $\left(^{-l-}\right)$ mice do not lose bone in a model of hindlimb disuse (tail suspension), showing the importance of OPN in bone remodeling. We report that $\mathrm{BSP}^{-I-}$ mice are viable and breed normally, but their weight and size are lower than wild-type (WT) mice. Bone is undermineralized in fetuses and young adults, but not in older $(\geq 12 \mathrm{mo}) \mathrm{BSP}^{-/-}$mice. At $4 \mathrm{mo}, \mathrm{BSP}^{-I-}$ mice display thinner cortical bones than WT, but greater trabecular bone volume with very low bone formation rate, which indicates reduced resorption, as confirmed by lower osteoclast surfaces. Although the frequency of total colonies and committed osteoblast colonies is the same, fewer mineralized colonies expressing decreased levels of osteoblast markers form in BSP-I- versus WT bone marrow stromal cultures. BSP-I- hematopoietic progenitors form fewer osteoclasts, but their resorptive activity on dentin is normal. Tail-suspended $\mathrm{BSP}^{-l-}$ mice lose bone in hindlimbs, as expected. In conclusion, BSP deficiency impairs bone growth and mineralization, concomitant with dramatically reduced bone formation. It does not, however, prevent the bone loss resulting from loss of mechanical stimulation, a phenotype that is clearly different from $\mathrm{OPN}^{-I-}$ mice.

\section{CORRESPONDENCE}

Jane E. Aubin:

jane.aubin@utoronto.ca

Abbreviations used: BFR, bone formation rate; $\mathrm{BMD}$, bone mineral density; BSP, bone sialoprotein; DMP, dentin matrix protein; IBSP, integrinbinding sialoprotein; MEPE matrix extracellular glycophosphoprotein; MLT, mineralization lag time; OPN, osteopontin; SIBLING, small, integrin-binding ligand $\mathrm{N}-$ linked glycoprotein; SPARC, secreted protein acidic and rich in cysteine; SPP, secreted phosphoprotein.
Proteins of the SIBLING (small, integrin-binding ligand $\mathrm{N}$-linked glycoprotein) (1) family (osteopontin/secreted phosphoprotein-1 [OPN/ SPP-1], bone sialoprotein/integrin-binding sialoprotein [BSP/IBSP], dentin sialophosphoprotein, dentin matrix protein-1 [DMP-1], and matrix extracellular glycophosphoprotein [MEPE]) comprise a structurally and phylogenetically homogeneous group of matricellular factors (2). Their genes are grouped as a "bone gene cluster" on human chromosome 4 (mouse chromosome 5) $(3,4)$, and they derive from a common ancestor shared with other enamel, milk, and saliva calcium-binding proteins, likely secreted protein acidic and rich in cysteine like-1 (SPARCL-1)/ Hevin, which is a relative of SPARC/osteonectin (5). Although originally thought to be restricted to mineralized tissues, the SIBLINGs are now known to be expressed in other tissues and organs, such as salivary glands (6) and kidney (7). The multiple functions of OPN (for review see [8]), which is one of the earliest known and the best studied members of the family, range from inflammation to lactation and cancer, suggesting that it is best described as a cytokine (9). The SIBLINGs interact with cells, especially via integrins, and with bone mineral, and are thus in a key position to regulate bone development, remodeling, and repair (1).

Although expression of DMP-1 and MEPE is restricted mainly to osteocytes, BSP (for review see [10]) and OPN have long been known to be highly expressed by osteoblasts, hypertrophic chondrocytes, and osteoclasts, where 
their functional roles are only beginning to be understood (1). In vitro data suggest that BSP (11), but not the ubiquitous OPN $(11,12)$, may initiate hydroxyapatite crystal formation in the bone matrix. Similar to OPN (13), BSP expression is increased in osteoblasts subjected to mechanical stimulation (14). Mice with the OPN gene ablated do not lose bone after mechanical unloading (tail suspension [15]) or upon estrogen withdrawal (ovariectomy [16]), showing the importance of OPN in the regulation of bone remodeling by osteoblasts and osteoclasts. These observations, together with their coexpression in osteogenic cells actively involved in bone deposition/remodeling, indicates the importance of establishing the functional specificities and degree of redundancy of OPN and BSP in the skeleton. To this end, we prepared and characterized knockout mice lacking expression of BSP $\left(\mathrm{BSP}^{-/-}\right)$, whose phenotype and response to tail suspension are distinct from $\mathrm{OPN}^{-1-}$ mice and other members of the SIBLING family.
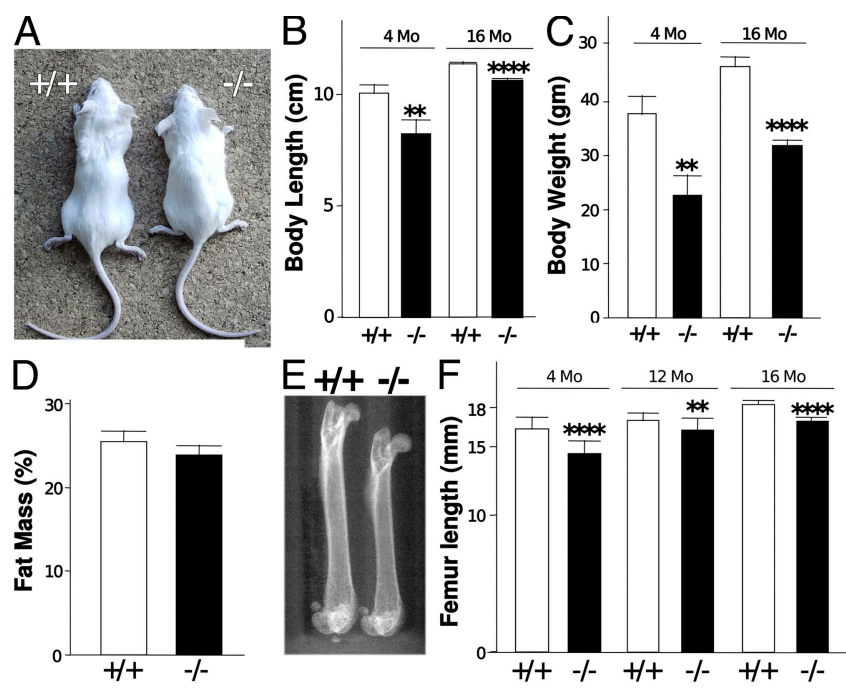

G
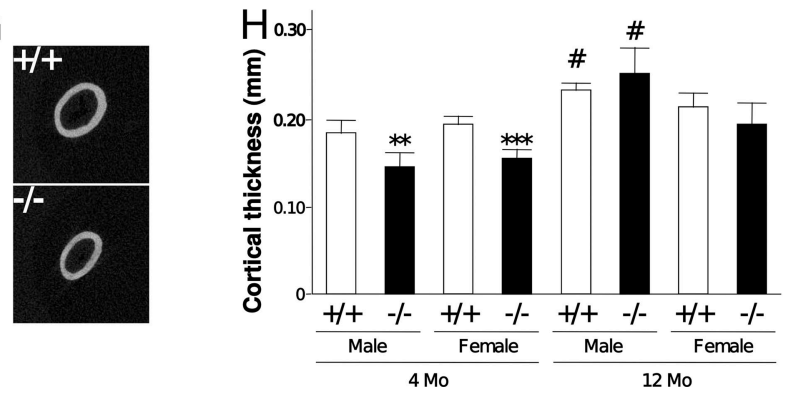

Figure 1. Morphology and skeletal morphometry of $\mathrm{BSP}^{-/-}$mice. Picture (A), measurements of body length (B), body weight (C), and percentage of fat mass (D) of ${ }^{+/+}$and ${ }^{-1-}$ mice. $\mu \mathrm{CT}$ scout images of whole femurs (E), and femur length (F) at 4 and 12 mo of age for WT $(+++)$ and mutant $\left(^{-1-}\right)$ female mice; similar results were obtained with males (not depicted). Two-dimensional images of midshaft sections in specimens from both genotypes $(\mathrm{G})$ and cortical thickness $(\mathrm{H})$ at 4 and 12 mo of age for ${ }^{+1+}$ and ${ }^{-1-}$ male and female mice. Values are the mean \pm the SEM of 6-10 samples. ${ }^{* *}, \mathrm{P}<0.01{ }^{* * * *}, \mathrm{P}<0.0001$ versus matched $\mathrm{WT} ; \#, \mathrm{P}<$ 0.05 versus matched females.
RESULTS

$\mathrm{BSP}^{-I-}$ mice are smaller and have shorter hypomineralized bones

$\mathrm{BSP}^{-/-}$mice are viable and breed normally with a Mendelian ratio of genotypes in progeny. However, the weight and size of both male and female $\mathrm{BSP}^{-/-}$mice are lower than their WT counterparts at $4 \mathrm{mo}$ and up to $16 \mathrm{mo}$ (Fig. 1, A-C). This is independent of nutritional deficit, as indicated by the percentage of fat in body mass, which does not differ between the two genotypes (Fig. $1 \mathrm{D}$ ). Bone size parameters parallel the overall size measurements, with shorter femora (Fig. 1, E and F) and thinner cortices (Fig. 1, G and H) in 4-moold mutants. Although with age cortical thickness of mutant bones reaches a size equivalent to that of WT (Fig. $1 \mathrm{H}$ ), femur length does not (Fig. 1 F). No difference in growth plate thickness in adult (4-6 mo old) $\mathrm{BSP}^{-/-}$versus WT mice was detectable (unpublished data).

Bone mineral density (BMD) of femurs of mutant mice is $20 \%$ lower than in WT mice at 4 mo of age, but equivalent in older mice (12 mo old; not depicted). Quantitative $\mu \mathrm{CT}$ analysis of midshaft femoral cortical bone showed that bone matrix mineralization (in milligrams of hydroxyapatite/centimeter ${ }^{3}$ ) is $\sim 9 \%$ lower in $\mathrm{BSP}^{-\prime-}$ mice compared with WT animals at birth (embryonic day [E]18 fetuses), and $\sim 5 \%$ lower at 4 mo of age, but not significantly different at $12 \mathrm{mo}$ of age (Table I). Quantitative microradiography (assessing the frequency distribution of mineral density on cortical and trabecular area of bone slices [17]) of a small sample of $\mathrm{BSP}^{-/-}$and WT male and female mice confirmed these findings (unpublished data).

\section{$\mathrm{BSP}^{-/-}$mice display high trabecular bone mass}

with low turnover

The trabecular bone volume (BV/TV) in long bones (Fig. 2, $\mathrm{A}$ and $\mathrm{B}$ ) of $\mathrm{BSP}^{-\prime-}$ male and female mice is $\sim 25-40 \%$ higher

Table I. Tissue mineralization of cortical bone, measured by $\mu \mathrm{CT}$ in femurs of WT and $\mathrm{BSP} \mathrm{P}^{-1-}$ mice

\begin{tabular}{|c|c|c|c|c|}
\hline Age & Sex & Genotype & $\mathrm{mg} \mathrm{HAP} / \mathrm{cm}^{3}$ & $\begin{array}{c}\text { \% Difference with } \\
+/+a\end{array}$ \\
\hline \multirow[t]{2}{*}{ E18 } & Fetus & $+/+$ & $269 \pm 12.6$ & \\
\hline & & $-1-$ & $245 \pm 10.4^{b}$ & $-8.90 \%$ \\
\hline \multirow[t]{4}{*}{$4 \mathrm{mo}$} & Male & $+/+$ & $1,331 \pm 23.0^{c}$ & \\
\hline & & $-1-$ & $1,266 \pm 30.0^{d, e}$ & $-4.90 \%$ \\
\hline & Female & $+/+$ & $1,378 \pm 10.5$ & \\
\hline & & $-1-$ & $1,313 \pm 17.8^{d}$ & $-4.70 \%$ \\
\hline \multirow[t]{4}{*}{$12 \mathrm{mo}$} & Male & $+/+$ & $1,468 \pm 40.8^{f}$ & \\
\hline & & $-1-$ & $1,465 \pm 16.4^{f}$ & $-0.20 \%$ \\
\hline & Female & $+/+$ & $1,344 \pm 23.3$ & \\
\hline & & $-1-$ & $1,310 \pm 9.2$ & $-2.50 \%$ \\
\hline
\end{tabular}

aSignificant differences with WT are shown in bold.

bP $<0.01$ versus matched WT.

cP $<0.01$ versus matched sex.

$\mathrm{dP}<0.001$ versus matched WT.

e $P<0.001$ versus matched sex.

$\mathrm{f} P<0.05$ versus matched sex. 
than in WT. This higher bone volume is associated with higher trabecular number $(\mathrm{TbN})$ and lower trabecular separation (TbSp) in mutant versus WT bones, although trabecular thickness tends to be smaller in mutant mice (Table II). Double fluorochrome labeling revealed a very low bone formation activity in 4-mo-old male and female $\mathrm{BSP}^{-/-}$compared with WT mice (Fig. $2 \mathrm{C}$ and Table II), both in terms of labeled surfaces (MS/BS) and apposition rate (MAR), resulting in a dramatically reduced bone formation rate (BFR). Low dynamic parameters of bone formation in $\mathrm{BSP}^{-/-}$mice cor-
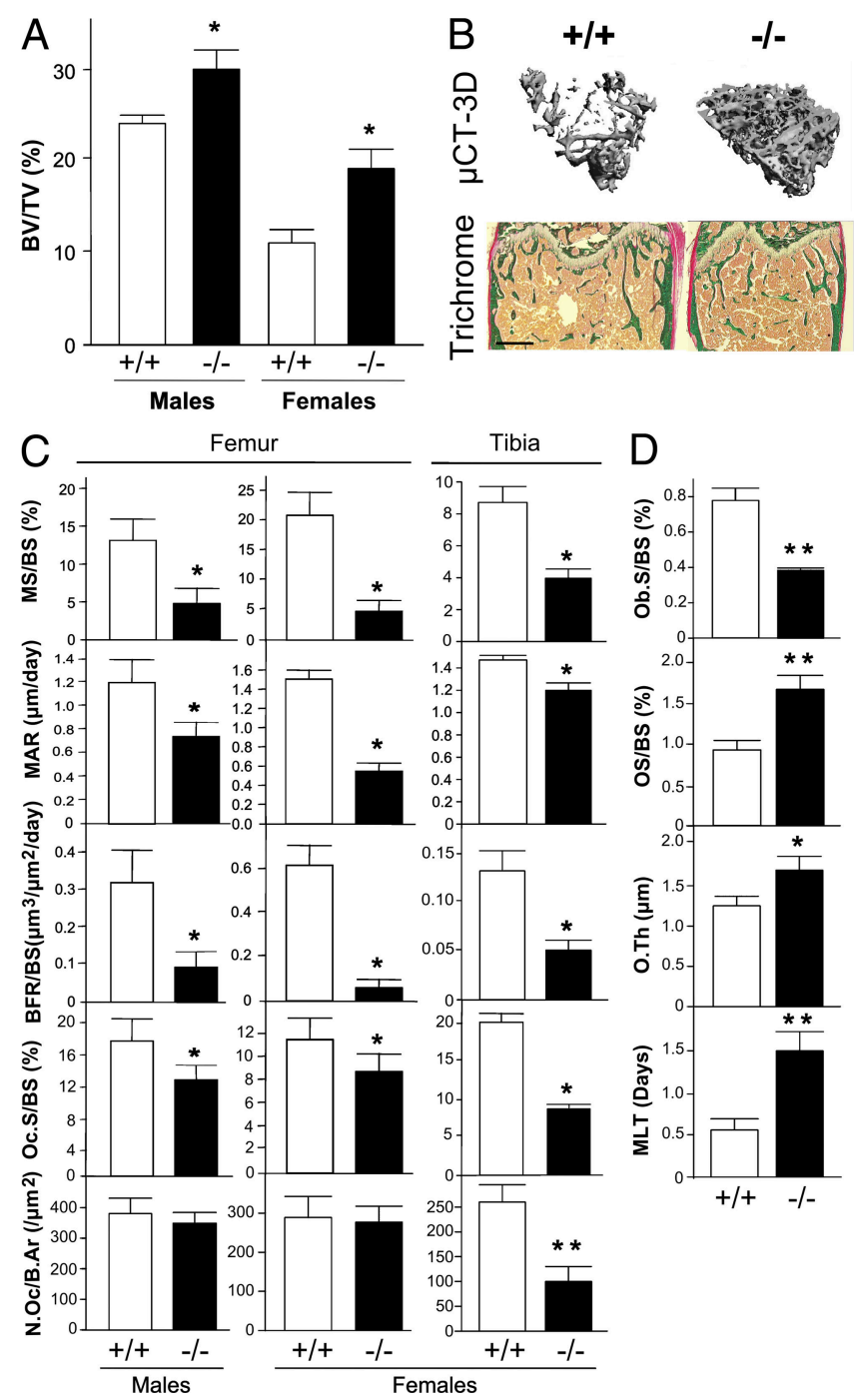

Figure 2. $\mathrm{BSP}^{-1-}$ mice have higher trabecular bone density and lower bone turnover. (A) Trabecular bone volume in tibias of 4-mo-old mutant $\left(^{-1-}\right)$ and WT $\left(^{++}\right)$mice of either sex as measured by three-dimensional $\mu \mathrm{CT}$. (B) Three-dimensional reconstruction and trichrome-stained sections of $+I_{+}$and $-1-$ female femur. Bar, $0.5 \mathrm{~mm}$. (C) Histomorphometric parameters of bone formation and resorption in the femur of male and female mice, and the tibia of female ${ }^{+/+}$and $-1-4$-mo-old mice. (D) Histomorphometric assessment of osteoblast surface and osteoid mineralization in the tibia of 4-mo-old ${ }^{+/+}$and ${ }^{-1-}$ female mice. All values are the mean \pm the SEM of 5 to 9 mice. ${ }^{*}, \mathrm{P}<0.05 ;{ }^{* *}, \mathrm{P}<0.01 ;{ }^{* * *}, \mathrm{P}<0.001$ versus matched ${ }^{+/+}$. relate with reduced surfaces of cuboidal (plump) osteoblasts (Ob.S/BS; Fig. 2 D). In contrast, osteoid surface (OS/BS) and thickness (O.Th) are increased in $\mathrm{BSP}^{-/-}$mice, as well as mineralization lag time (MLT; Fig. 4 D), reflecting delayed primary mineralization. Osteoclast surfaces (Oc.S/BS) are reduced in mutant compared with WT femur of both sexes (Fig. 2 C). A similar phenotype is observed in tibia, where osteoclast numbers (N.Oc/B.Ar) were also found to be significantly reduced in $\mathrm{BSP}^{-/-}$mice (Fig. $2 \mathrm{C}$ ).

\section{Both bone nodule mineralization and osteoclast} differentiation are impaired in cultures of $\mathrm{BSP}^{-l-}$ cells Total mesenchymal progenitor cell (total CFU-F) and osteoprogenitor frequency were assessed in WT and mutant male and female bone marrow stromal cell cultures (Fig. 3 A). In
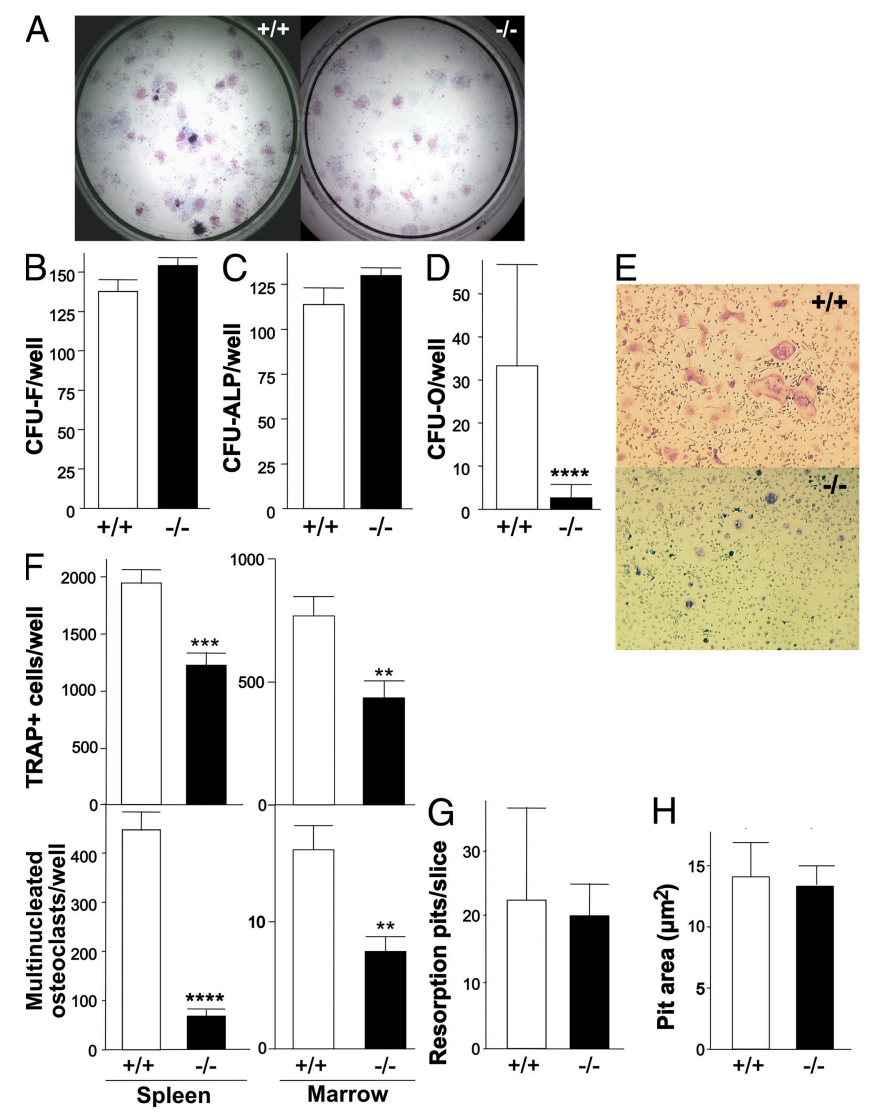

Figure 3. Impaired mineralized bone nodule formation and osteoclast differentiation, but not activity, in cultures of BSP-I- cells. Micrographs (A) and quantification of total colony forming units-fibroblasts (CFU-F; B), unmineralized ALP+ colonies (CFU-ALP; C) and mineralized $\mathrm{ALP}^{+}$colonies (CFU-O; $\mathrm{D}$ ) in bone marrow stromal cell cultures of female mutant $\left(^{-l-}\right)$ and WT $\left(^{++}\right)$mice. Values are the mean \pm the SEM of 8-15 wells. (E) Micrographs of $+1++$ and $-1-$ female spleen cells grown with RANKL+M-CSF and stained for TRAP activity (TRAP+); (F) number of TRAP ${ }^{+}$ cells; $(G)$ number of osteoclasts (TRAP+ cells with $\geq 3$ nuclei) formed in spleen cell and bone marrow cultures. Values are the mean \pm the SEM of 12 wells. (H) Number of resorption pits on dentine slices plated with ${ }^{+/+}$ and ${ }^{-1-}$ differentiated osteoclasts; values are the mean \pm the SEM of six slices. ${ }^{* * *}, P<0.001 ; * * *, P<0.0001$ versus matched WT. 
Table II. Static and dynamic trabecular bone parameters in long bones of control and unloaded WT (WT) and BSP-I- mice

\begin{tabular}{|c|c|c|c|c|c|}
\hline \multirow{2}{*}{$\frac{\text { Genotype }}{\text { Treatment }}$} & \multicolumn{2}{|c|}{ WT } & \multicolumn{2}{|c|}{$\mathrm{BSP}^{-1-}$} & \multirow[b]{2}{*}{ Sex } \\
\hline & Control & Unloaded & Control & Unloaded & \\
\hline \multicolumn{6}{|c|}{$\overline{\text { Static parameters }}{ }^{\mathrm{a}}$} \\
\hline SMI & $2.3 \pm 0.1$ & $3.0 \pm 0.1^{b, c}$ & $1.7 \pm 0.1^{d}$ & $2.0 \pm 0.1^{\mathrm{e}}$ & Male \\
\hline $\begin{array}{l}\text { Tb.N } \\
(/ \mathrm{mm})\end{array}$ & $3.6 \pm 0.2$ & $2.3 \pm 0.2^{\mathrm{e}}$ & $6.1 \pm 0.3^{f}$ & $5.4 \pm 0.3^{e}$ & \\
\hline $\begin{array}{l}\text { Tb.Th } \\
(\mu \mathrm{m})\end{array}$ & $51 \pm 1.8$ & $46 \pm 0.8^{e}$ & $53 \pm 1.6$ & $48 \pm 1.1^{e}$ & \\
\hline $\begin{array}{l}\text { Tb.Sp } \\
(\mu \mathrm{m})\end{array}$ & $30 \pm 2.6$ & $39 \pm 3.2^{\mathrm{e}}$ & $16 \pm 0.8^{g}$ & $18 \pm 1.1^{e}$ & \\
\hline$n$ & 9 & 12 & 6 & 6 & \\
\hline SMI & $2.1 \pm 0.1$ & $2.4 \pm 0.04^{e}$ & $2.2 \pm 0.1$ & $2.6 \pm 0.1^{\mathrm{h}}$ & Female \\
\hline $\begin{array}{l}\text { Tb.N } \\
(/ \mathrm{mm})\end{array}$ & $2.1 \pm 0.1$ & $2.4 \pm 0.2$ & $3.7 \pm 0.3^{9}$ & $3.2 \pm 0.3^{i}$ & \\
\hline $\begin{array}{l}\text { Tb.Th } \\
(\mu \mathrm{m})\end{array}$ & $67 \pm 1.4$ & $53 \pm 2.0^{i}$ & $47 \pm 1.6^{f}$ & $46 \pm 2.1$ & \\
\hline $\begin{array}{l}\text { Tb.Sp } \\
(\mu \mathrm{m})\end{array}$ & $50 \pm 3.0$ & $44 \pm 3.3$ & $28 \pm 2.5^{9}$ & $34 \pm 4.2$ & \\
\hline$n$ & 7 & 8 & 6 & 8 & \\
\hline \multicolumn{6}{|c|}{ Dynamic parametersj } \\
\hline $\begin{array}{l}\text { N.Oc/B.Ar } \\
\left(/ \mu m^{2}\right)\end{array}$ & $379 \pm 50$ & $383 \pm 42$ & $346 \pm 39$ & $354 \pm 65$ & Male \\
\hline $\begin{array}{l}\text { MS/BS } \\
(\%)\end{array}$ & $13.04 \pm 2.69$ & $6.14 \pm 1.41^{e}$ & $4.93 \pm 1.68^{k}$ & $1.18 \pm 0.27^{h}$ & \\
\hline $\begin{array}{l}\text { MAR } \\
(\mu \mathrm{m} / \text { day })\end{array}$ & $2.38 \pm 0.36$ & $1.31 \pm 0.10^{h}$ & $1.49 \pm 0.19^{k}$ & $1.55 \pm 0.88$ & \\
\hline$n$ & 9 & 9 & 7 & 9 & \\
\hline $\begin{array}{l}\text { N.Oc/B.Ar } \\
\left(/ \mu m^{2}\right)\end{array}$ & $288 \pm 50$ & $384 \pm 63$ & $277 \pm 38$ & $386 \pm 37$ & Female \\
\hline $\begin{array}{l}\text { MS/BS } \\
(\%)\end{array}$ & $21.51 \pm 3.19$ & $6.38 \pm 1.53^{i}$ & $4.93 \pm 1.34^{9}$ & $5.28 \pm 1.12$ & \\
\hline $\begin{array}{l}\text { MAR } \\
(\mu \mathrm{m} / \mathrm{day})\end{array}$ & $2.98 \pm 0.18$ & $1.18 \pm 0.22^{i}$ & $1.11 \pm 0.14^{g}$ & $1.17 \pm 0.13$ & \\
\hline$n$ & 9 & 10 & 7 & 7 & \\
\hline
\end{tabular}

See Materials and methods for details.

${ }^{a} \mu \mathrm{CT}$ analysis on excised tibias.

${ }^{b} \mathrm{P}<0.0001$ versus loaded control.

cResults are the mean \pm the SEM.

$\mathrm{dP}<0.01$ versus matched WT.

eP $<0.05$ versus loaded control.

${ }^{\mathrm{f}} \mathrm{P}<0.0001$ versus matched WT.

${ }^{g} \mathrm{P}<0.001$ versus matched WT.

$\mathrm{hP}<0.01$ versus loaded control.

i $P<0.001$ versus loaded control.

iHistomorphometry on excised femurs.

${ }^{k P}<0.05$ versus matched WT.

cultures from both sexes (males not depicted), the total number of CFU-F (Fig. $3 \mathrm{~B}$ ) and the subset of putative osteoprogenitors $\left(\mathrm{CFU}-\mathrm{ALP}=\right.$ colonies with $\mathrm{ALP}^{+}$cells, but unmineralized matrix; Fig. $3 \mathrm{C}$ ) is the same in $\mathrm{BSP}^{-1-}$ and WT stromal cells, but the number of mature osteoblast colonies $(\mathrm{CFU}-\mathrm{O}=$ colonies double-positive for ALP activity and mineral deposition) is dramatically reduced (Fig. 3, A and D). A significantly
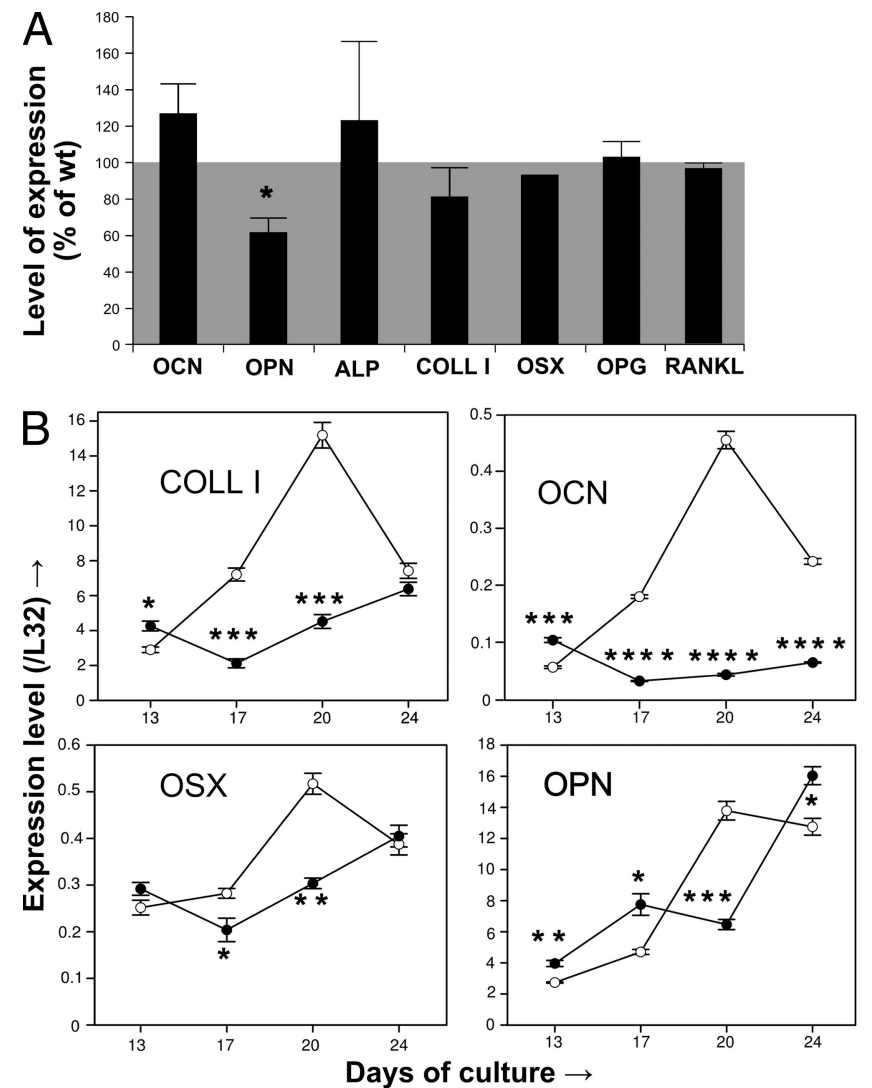

Figure 4. In vivo and in vitro effects of BSP deletion on osteoblast marker expression. (A) Real-time PCR analysis of osteocalcin (OCN), OPN, tissue nonspecific alkaline phosphatase (ALP), type I collagen (COLL I), osterix (OSX), osteoprotegerin (OPG), and receptor-activator of NF- $\mathrm{BB}$ (RANKL) mRNA expression in femurs of 4-mo-old male BSP-1- mice. Values are the mean \pm the SEM of 3-4 mice (except for OSX) normalized to housekeeping gene L32 and expressed as the percentage of WT levels. (B) Time course of expression of COLL I, OCN, OSX, and OPN mRNA as assessed by real-time PCR in bone marrow cultures of WT (empty symbols) and mutant (black symbols) mice, grown in osteogenic conditions. Values were normalized to time-matched levels of the housekeeping gene L32. ${ }^{*}, \mathrm{P}<0.05 i^{* *}, \mathrm{P}<0.01 i^{* * *}, \mathrm{P}<0.001 ;{ }^{* * *}, \mathrm{P}<0.0001$ versus matched WT.

lower number of TRAP-positive cells and of multinucleated osteoclasts form in spleen cells (Fig. 3, E and F) and bone marrow cultures (Fig. $3 \mathrm{~F}$ ) from $\mathrm{BSP}^{-1-}$ versus WT mice. Although osteoclasts formed in $\mathrm{BSP}^{-/}$cultures appear smaller than those in WT cultures (Fig. 3 E), when differentiated, osteoclasts were replated onto dentine slices. No significant difference in either the number (Fig. $3 \mathrm{G}$ ) or the mean area (Fig. $3 \mathrm{H}$ ) of resorption pits was observed between the two genotypes.

\section{$\mathrm{BSP}^{-1-}$ mice express aberrant levels of osteoblast markers}

Expression of major osteoblast markers was assessed by quantitative RT-PCR of RNA from long bones of 4-mo-old mutant and WT mice; OPN expression is decreased in $\mathrm{BSP}^{-/-}$bones, whereas all other markers tested do not vary significantly (Fig. 4 A). Real-time PCR analysis of osteoblast marker expression 

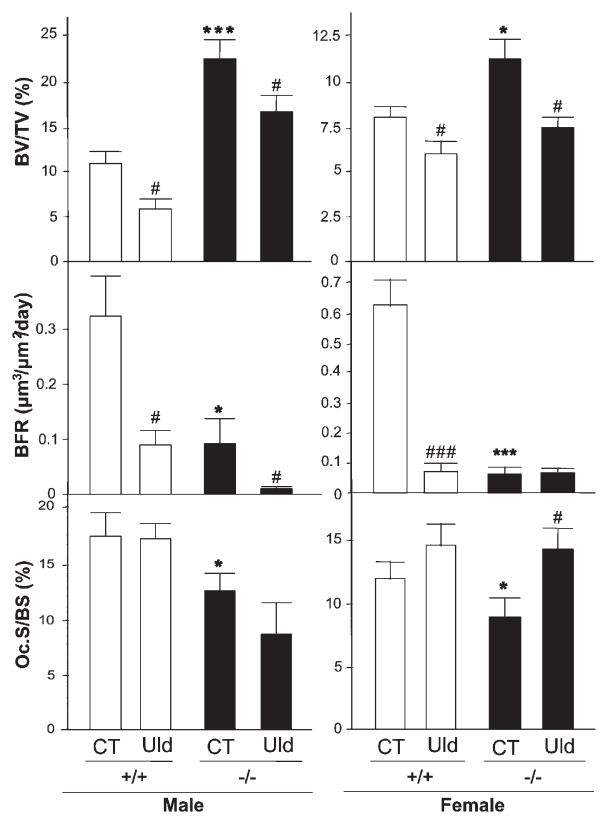

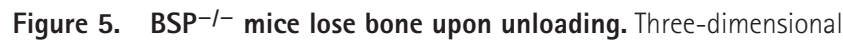
$\mu \mathrm{CT}$ assessment of trabecular bone volume in tibia, and histomorphometric assessment of BFR and osteoclast surfaces (Oc.S/BS) in femur of mutant $\left(^{(-)}\right)$and WT $\left({ }^{++}\right)$control (CT) or 15-d tail-suspended (Unloaded, Uld) male and female mice. Values are the mean \pm the SEM of 7-9 samples. ${ }^{*}, \mathrm{P}<0.05 ;{ }^{* *}, \mathrm{P}<0.01 ;{ }^{* * *}, \mathrm{P}<0.001$ versus matched $\mathrm{CT}$.

in differentiating cultures showed higher levels of mRNAs for all markers in early cultures (day 13; day 17 for OPN), but reduced (osteocalcin) or delayed peak expression (all other markers) in later cultures (Fig. 4 B).

\section{$\mathrm{BSP}^{-/-}$mice lose bone under conditions of unloading}

Both male and female WT and $\mathrm{BSP}^{-/-}$mice lose trabecular bone in the tibiae after $2 \mathrm{wk}$ of tail suspension (Fig. 5 and Table II). Changes in BV/TV parallel other structural parameters of trabecular bone (Table II). As previously described in unloaded mice (18), trabecular bone loss in WT mice correlates with a dramatic decrease in BFR (Fig. 5) caused by a significant reduction of both MS/BS and MAR (Table II). BFR decrease upon unloading is detected in mutant males (Fig. 5). Osteoclast surface is also increased by hindlimb unloading in both genotypes, at least in females (Fig. 5), whereas osteoclast numbers show a nonsignificant trend to increase (Table II).

\section{DISCUSSION}

The close phylogenic relationship between SIBLING family members (5), as well as their marked structural similarities $(1,19)$, raise questions about their functional specificities, especially in the context of bone. Indeed, mouse models in which particular SIBLINGs are knocked out (20-24) have displayed a variety of distinct phenotypes. For instance, both DMP1 and MEPE strongly regulate bone mineralization, but in opposite ways, with absence of the former leading

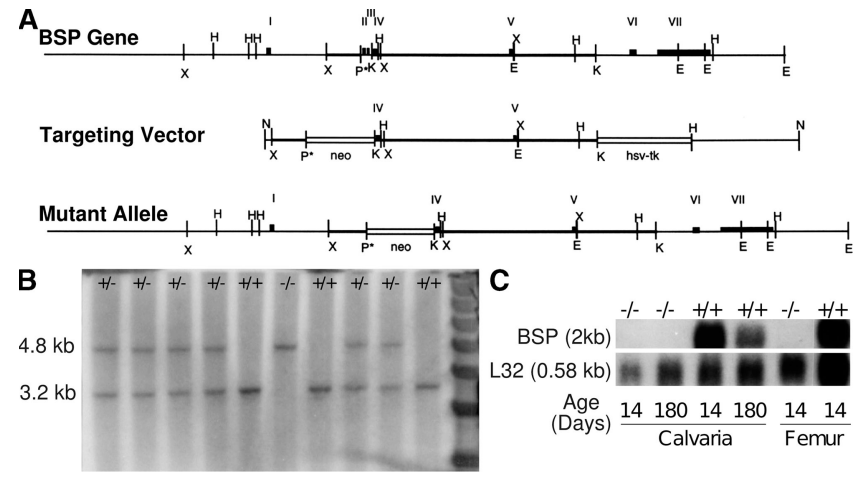

Figure 6. Strategy for deletion of the bsp gene. (A) A schematic representation of the WT and mutant alleles and the targeting vector. $E_{1}$ EcoRI; H, HindIII; B, BamHI; X, Xbal; N, Notl; K, Kpn. (B) Southern blot analysis of tail DNA from WT $\left({ }^{++}\right)$, heterozygote $\left(^{(+-}\right)$and knockout $\left(^{(-/-}\right)$ mouse littermates. The presence of the 3.2-kb wild-type fragment and the 4.8-kb recombinant fragments are seen in genomic DNA digested with HindIII. (C) Northern blot analysis of BSP mRNA expression in calvaria and femur bones of young and adult ${ }^{+/+}$and ${ }^{-1-}$ mice. L32, housekeeping gene.

to osteomalacia (23), at least in part through up-regulation of FGF23 (24) and MEPE (25), whereas absence of the latter results in high bone mass (22). Similarly, studies in vitro under carefully controlled conditions suggest that OPN is a strong inhibitor of hydroxyapatite crystal growth, whereas BSP (11) and DMP-1 (26) are promoters of mineralization. The recent characterization of OPN/ALP double-knockout mice, in which the osteomalacia caused by the lack of ALP activity is partly rescued by the absence of OPN, supports a role for OPN as a mineralization inhibitor (27). Interestingly, $\mathrm{OPN}^{-1-}$ mice were also reported to have hypermineralized bone matrix $(27,28)$, in striking contrast to the hypomineralization that we document in BSP knockout mice. BSP was shown to be associated with bone acidic glycoprotein-75 and ALP in specific structures ("biomineralization foci") that are sites of mineral nucleation in the matrix of primary membrane bone $(29,30)$. The hypomineralization of bone nodules formed in cultures of cells from $\mathrm{BSP}^{-/-}$mice, the slight but significant mineral deficit in $\mathrm{BSP}^{-/-}$mice at birth $(\sim 9 \%)$, and the increased MLT in adult bone are compatible with a role of BSP in early bone matrix mineralization, whereas the progressive recovery with age of matrix mineral content (Table I) would suggest that this protein has no major and/ or a redundant function in mature bone. However, the reduced expression of OPN in whole $\mathrm{BSP}^{-/-}$bones and the delayed peak of OPN in osteogenic mutant marrow cultures suggest a more complex situation in which down-regulation of OPN may be a compensatory response to loss of BSP, and more work is needed to establish the part played by each SIBLING family member in the development and regulation of matrix mineralization.

Although the affinity of SIBLINGs for hydroxyapatite and the ability to regulate crystal growth/nucleation were among the earliest characteristics identified for members of 
Table III. PCR primers in $5^{\prime}-3^{\prime}$ direction

\begin{tabular}{|c|c|c|c|}
\hline Gene & Sequence ${ }^{a}$ & PrimerBank ID & $\begin{array}{l}\text { Product } \\
\text { size (bp) }\end{array}$ \\
\hline ALP & $\begin{array}{l}\text { F-CCAACTCTITGTGCCAGAGA } \\
\text { R-GGCTACATGGTGTGAGCTIT }\end{array}$ & 6671533a1 & 110 \\
\hline Col1 $\alpha 1$ & $\begin{array}{l}\text { F-GCTCCTCTAAGGGGCCACT } \\
\text { R-CCACGTCTCACCATTGGGG }\end{array}$ & $34328108 a 1$ & 103 \\
\hline $\mathrm{L} 32^{\mathrm{b}}$ & $\begin{array}{l}\text { F-CACAATGTCAAGGAGCTGGAAGT } \\
\text { R-TCTACAATGGCITICGGTCT }\end{array}$ & NA & 100 \\
\hline $\mathrm{OCN}$ & $\begin{array}{l}\text { F-CTGACCTCACAGATGCCAAGC } \\
\text { R-TGGTCTGATAGCTCGTCACAAG }\end{array}$ & 13811695a1 & 187 \\
\hline OPN & $\begin{array}{l}\text { F-AGCAAGAAACTCTTCCAAGCAA } \\
\text { R-GTGAGATTCGTCAGATTCATCCG }\end{array}$ & $6678113 a 1$ & 134 \\
\hline OSX & $\begin{array}{l}\text { F-ATGGCGTCCTCTCTGCTTG } \\
\text { R-TGAAAGGTCAGCGTATGGCTT }\end{array}$ & 18485518a 1 & 156 \\
\hline OPG & $\begin{array}{l}\text { F-GGGCGTACCTGGAGATCG } \\
\text { R-GAGAAGAACCCATCTGGACATT }\end{array}$ & $31543882 \mathrm{a} 2$ & 125 \\
\hline RANKL & $\begin{array}{l}\text { F-CCAGCTATGATGGAAGGCTCA } \\
\text { R-CGTACAGGTAATAGAAGCCA }\end{array}$ & NA & 223 \\
\hline
\end{tabular}

$N A_{\text {, not available. }}$

aF, forward; $R$, reverse

${ }^{b}$ Designed with Primer Express software, version 2.0 (PerkinElmer).

this family, it is now clear that these proteins are involved in numerous other physiological processes. For example, recent investigations have implicated SIBLINGs in the regulation of MMP activity (31). This, together with their well-known capacity to mediate cell attachment (32-36), suggests that SIBLINGs are important factors in normal and pathogenic tissue remodeling, e.g., in cancer (37-40), and possibly in bone. The latter hypothesis is supported by the phenotype of $\mathrm{BSP}^{-1-}$ mice.

The shorter size of $\mathrm{BSP}^{-/-}$mice correlates with the reduced size of long bones. The complex process of endochondral ossification involves interplay between osteoblasts and chondrocytes, two BSP-expressing cell types (the latter at the hypertrophic stage), as well as vascularization, in which BSP may play a regulatory role (41). Detailed studies are being carried out to describe precisely at the tissue level the time course of skeletogenesis and long bone growth in $\mathrm{BSP}^{-1-}$ mice, and clarify the cell types and mechanisms affected by BSP deletion.

The reduced cortical thickness and $\mathrm{BFR}$ of $\mathrm{BSP}^{-/-}$mice are consistent with both the expression of BSP in actively bone forming/remodeling cells and its known and putative functions in cell attachment and tissue processing. Together with several previous in vitro studies (42-46), these results indicate that BSP is a potent regulator of osteoblast differentiation and/or activity. It is also notable that the absence of BSP does not appear to alter the total mesenchymal progenitor cell pool, osteoprogenitor recruitment, or early differentiation, as the total number of CFU-F and CFU-ALP is not detectably changed. However, the strikingly lower number of mineralized colonies indicates that BSP is required for late stages of (at least) primary osteogenesis. This is confirmed by
RT-PCR results documenting an altered expression of late osteoblast markers, perhaps matrix-driven (low type I collagen), in $\mathrm{BSP}^{-/-}$marrow cultures, which is likely to impair the deposition of mineralized matrix. Our results are in agreement with recent data from osteoblasts treated with siRNA of intact and mutant BSP (46), which also indicate that the RGD-containing portion of the sequence is necessary for phenotypic regulation by BSP. These in vitro data are consistent with the low rate of bone formation observed in vivo, and thus the observation that $\mathrm{BSP}^{-1-}$ mice actually display a higher trabecular bone mass strongly suggests that bone resorption is concomitantly reduced.

It is notable that the loss of BSP does not affect osteoclast capacity to resorb normal (BSP-containing) dentine, suggesting that endogenous BSP production by osteoclasts is not required for resorption. On the other hand, absence of BSP does impair osteoclast differentiation in vitro, which is consistent with previous in vitro studies implicating BSP in regulation of osteoclast differentiation and activity (47), together with RANKL (48). That the same is true in vivo is supported by our observation that, whereas OPG and RANKL expression are normal, there is a reproducible reduction of the percentage of area covered by osteoclasts in $\mathrm{BSP}^{-1-}$ mice, and a less consistent reduction in osteoclast numbers. Osteoclasts and their precursors adhere to BSP through the $\alpha v \beta 3$ integrin receptor, and this interaction is thought to be an important regulator of their differentiation and activity $(47,49)$. It is thus possible that the differentiation of osteoclasts and, as is the case for $\mathrm{OPN}^{-/-}$mice (50), their resorptive activity in vivo (on matrix lacking BSP), is significantly impaired via an integrin outside-in pathway, but further studies will be necessary to clarify this point.

Overall, the phenotype of $\mathrm{BSP}^{-/-}$mice strikingly contrasts that seen in $\mathrm{OPN}^{-/-}$mice. The latter have a normal BFR, but a higher trabecular bone mass with increased numbers of poorly resorbing osteoclasts (50). Also, as previously mentioned, $\mathrm{OPN}^{-/-}$mice do not lose bone with hindlimb unloading, which is an established model of disuse osteoporosis (15). In contrast, and despite their low turnover, mice lacking BSP respond to hindlimb unloading by a significant trabecular bone loss. As previously shown (18), hindlimb unloading induces a transient increase of bone resorption followed by a more sustained inhibition of bone formation. After $15 \mathrm{~d}$ of unloading, WT mice show strongly reduced BFR with only a trend to increased osteoclast numbers and (in females) surfaces in our experiments, indicative of a latestage bone response. In $\mathrm{BSP}^{-/-}$mice, $\mathrm{BFR}$ reduction is observed only in males, whereas the increased osteoclast surface is seen only in females, likely caused by distinct kinetics between the two sexes. Collectively, our data suggest that osteoblastic formation and osteoclastic resorption are modulated by unloading in $\mathrm{BSP}^{-/-}$mice, the latter likely accounting for most of the bone loss, given the low BFR. Although, as mentioned, our in vitro results on dentin cannot discount reduced in vivo osteoclast activity in $\mathrm{BSP}^{-/-}$mice, older mutant animals do lose trabecular bone (not depicted), which is 
suggestive of efficient metaphyseal resorption in mature $(>5$ mo-old) animals. Collectively, these results suggests that BSP is not an absolute limiting factor for increased resorption, perhaps caused by some compensatory mechanisms, such as overexpression of related proteins (possibly another SIBLING) in challenging conditions. Whatever the compensatory mechanism, it contrasts with the cell autonomous defect in osteoclast activity of $\mathrm{OPN}^{-/-}$mice (50), and stresses that the cellular mechanisms underlying the two phenotypes are quite different.

In conclusion, $\mathrm{BSP}^{-/-}$mice display a reduced body and long bone growth, but have a high trabecular bone mass accompanied by low bone turnover that is, nonetheless, responsive to mechanical challenges. Our data thus highlight the specificity of BSP roles in the bone context and further confirm the nonredundancy of function of SIBLING family members in skeletal biology.

\section{MATERIALS AND METHODS}

Construction of the $b s p$-null targeting vector and chimeric mouse production. Two $b s p$ mouse cDNA clones were used to screen a $129 \mathrm{~Sv} / \mathrm{J}$ mouse genomic $\lambda$ DASH2 phage library. 2 overlapping genomic clones, spanning $\sim 19 \mathrm{~kb}$ of sequence and the entire $b s p$ locus, were isolated and sequenced. A short $5^{\prime}$ arm of bsp homology on a 600-bp Sac1 fragment downstream of exon I was cloned upstream of the PGKneo cassette in the pPNT positive-negative selection vector. A long $3^{\prime}$ arm of bsp homology on a 6-kb Kpn fragment was then cloned downstream of the PGKneo cassette, giving the final targeting vector. Homologous recombination resulted in the deletion of exons II-III and insertion of the PGKneo cassette in their place (Fig. 6 A). Mouse embryonic stem cells (R1; passage 8) were provided by A. Nagy (Samuel Lunenfeld Research Institute, Mount Sinai Hospital, Toronto, Ontario, Canada) (51). Propagation, electroporation, and selection of recombinant R1 clones were performed essentially as previously described (52). In brief, RI embryonic stem cells were electroporated with the NotI linearized targeting vector and were selected by using $200 \mu \mathrm{g}$ of active Geneticin (G418; Invitrogen)/ml and $2 \mu \mathrm{M}$ ganciclovir (Syntex, Inc.). DNA from selected clones was digested with HindIII and analyzed by Southern blot hybridization using a HindIII/Xba probe as indicated (Fig. 6 B). Positive clones were used to make chimeric mice, among which a male transmitted the mutation through the germ line after crossing with albino CD1 outbred females. Offspring were maintained on a 129/CD-1 background and genotyped by Southern blotting. Northern blotting of total RNA extracted from calvariae and long bones of WT and $\mathrm{BSP}^{-/-}$mice, with the ribosomal protein L32 as a control, confirmed the total lack of BSP expression in knockout mice (Fig. 6 C).

Care of animals and sampling procedures. The procedures for the care and killing of the animals were in accordance with the University of Toronto Animal Care Committee and the European Community standards on the care and use of laboratory animals (Ministère de l'Agriculture, France; Authorization 04827). The animal experiments were approved by the local Animal Care Committees. During acclimatization and experimentation, the animals were kept in standard conditions of temperature $\left(23 \pm 2^{\circ} \mathrm{C}\right)$ and light-controlled environment (12 h light/12 h dark cycle), and with free access to water and pelleted food (UAR rodent diet No.R03-25; UAR).

Measurement of body and skeletal parameters. After killing, mouse body length was measured from the nose to the tip of the tail. Biphotonic densitometry was used to measure BMD (Hologic QDR 1500) and fat mass (Piximus; Lunar Corp.). Femur length was measured on isolated bones with a $1 / 50$ caliper between the olecranon and the articular condyle of the knee.
Hindlimb unloading. 16-wk-old male and female $\mathrm{BSP}^{-/-}$and WT mice were either subjected to hindlimb unloading through tail suspension or kept unsuspended ( $n=10$ per treatment group) for 15 d. Each suspended and control animal was single-housed in a polycarbonate cage $(26 \times 15 \times 14$ $\mathrm{cm})$; suspended cages were raised by a frame supporting the suspension hanging system. Tail suspension experiments were performed with standard housing conditions as above. After sacrifice, the long bones were dissected out and processed for histomorphometry and/or $\mu \mathrm{CT}$, as described in these sections.

Histology and histomorphometry. Fetuses at term (E18) and bones from adult specimens were processed undecalcified for histology. 6 and $2 \mathrm{~d}$ before death, adult animals were labeled with $25 \mathrm{mg} / \mathrm{kg}$ tetracycline by intraperitoneal injection. Mice were killed by cervical dislocation, and long bones were dissected out and fixed in 3.7\% paraformaldehyde in PBS. Fetuses were fixed and dehydrated in the same way. Undecalcified bone samples were embedded in methylmethacrylate, and longitudinal coronal slices were cut with a Jung model K microtome (Reichert-Jung) and used for modified Goldner staining, tartrate-resistant acid phosphatase (TRAP) staining (without counterstaining) of osteoclasts, or left unstained. Trabecular bone volume (BV/TV), osteoblast surface (Ob.S/BS), osteoid surface (OS/BS), and thickness (O.Th) were measured on Goldner-stained sections. Dynamic bone remodeling parameters were measured by histomorphometry after double-tetracyclin labeling (on unstained sections for labeled surfaces [MS/BS], mineral apposition rate [MAR], and BFR [BFR/BS]). These parameters were combined to assess osteoid mineralization through MLT $(\mathrm{MLT}=[\mathrm{O} . \mathrm{Th} \times \mathrm{OS}] / \mathrm{MS} \times \mathrm{MAR}])$ and Osteoid Maturation Time (OMT $=$ O.Th/MAR). Osteoclast surfaces (Oc.S/BS) and numbers (N.Oc/B.Ar) were measured on TRAP-stained sections. Fetus sections were stained with von Kossa for mineral or toluidine blue for cartilage. Quantitative microradiography was done on 100- $\mu \mathrm{m}$-thick sections of tibiae from 10-mo-old mice, and bone matrix mineralization (grams/ centimeter $^{3}$ ) was measured as previously described (17).

High-resolution $\boldsymbol{\mu C T}$. Fetuses at term (E18), fixed and ethanol-dehydrated bones dissected from adult specimens, and whole mice were scanned with a high-resolution $\mu \mathrm{CT}$ (Viva CT40; Scanco Medical). Fetuses and isolated bones were kept in ethanol during image acquisition. Whole mice were killed by cervical dislocation before scanning. Data were acquired at 55 $\mathrm{KeV}$ for adults and $45 \mathrm{KeV}$ for fetuses, with $10 \mu \mathrm{m}$ cubic resolution. Threedimensional reconstructions were generated with the following parameters: Sigma, 1.2; Support, 2; Threshold, 160 (spongiosa) or 280 (cortex) for adult samples and Threshold, 140 for fetuses. Cortical thickness and tissue mineral density were calculated by integration of the value on each transverse section of a set of 100 chosen in the midshaft area. Tissue mineral density was derived from the linear attenuation coefficient of thresholded bone through precalibration of the apparatus for the acquisition voltage chosen. The bone volume fraction of trabecular metaphysis (VOX BV/TV) was measured on a set of 80 sections under the growth plate, within the secondary spongiosa. Trabecular thickness (Tb.Th), trabecular number (Tb.N), trabecular separation (Tb.Sp), and structure model index (SMI) were calculated without assuming a constant model, as previously described (53). SMI estimates the plate-rod characteristics of a structure; its value is 0 for an ideal plate, and 3 for an ideal rod, with intermediate values reflecting the volume ratio between rods and plates.

In vitro osteoblast and osteoclast differentiation and activity assays. Mouse bone marrow stromal cell cultures were used to quantify the total number of progenitors: total colony forming units-fibroblasts (CFU-F; methylene blue-positive colonies), colony forming units-tissue nonspecific alkaline phosphatase (CFU-ALP, i.e., putative osteoprogenitors expressing ALP), and definitive osteoblastic cells with mature osteoblasts and mineralized matrix (CFU-O; ALP and von Kossa-positive, mineralized colonies) as previously described $(54,55)$. In brief, young $(2-4$ mo of age) male and female $\mathrm{BSP}^{-/-}$and WT mice were killed by cervical dislocation, and the marrow was flushed from dissected femurs in $\alpha$-minimum essential medium 
$(\alpha M E M)$ with antibiotics $(100 \mu \mathrm{g} / \mathrm{ml}$ penicillin G [Sigma-Aldrich], $50 \mu \mathrm{g} / \mathrm{ml}$ gentamycin [Sigma-Aldrich], and $300 \mathrm{ng} / \mathrm{ml}$ fungizone [Flow Laboratories]) containing $15 \%$ heat-inactivated FCS. Recovered cells were plated at $0.5-1 \times$ $10^{6}$ nucleated cells $/ 35-\mathrm{mm}$ dish and cultured in the same medium, which was supplemented additionally with ascorbic acid $(50 \mu \mathrm{g} / \mathrm{ml})$ and $\beta$-glycerophosphate $(10 \mathrm{mM})$. Cultures were maintained for $18-21 \mathrm{~d}$; fixing, staining, and quantification of colony numbers was carried out as previously described $(54,55)$.

For osteoclast differentiation assays, $\mathrm{BSP}^{-/-}$and WT female mice were killed by cervical dislocation. Spleens were removed and osteoclast precursors were isolated by centrifugation using Lympholyte cell separation media (CL 5030; Cedarlane Laboratories) for $20 \mathrm{~min}$ at 2,500 rpm. Cells were plated in 24-well plates at $25 \times 10^{4}$ cells per well, in differentiation medium containing $50 \mathrm{ng} / \mathrm{ml} \mathrm{RANKL}$ and $20 \mathrm{ng} / \mathrm{ml} \mathrm{MCSF}$ (Peprotech). Bone marrow was collected, plated $\left(2 \times 10^{6}\right.$ nucleated cells $\left./ \mathrm{cm}^{2}\right)$, and grown as described in the previous paragraph in $\alpha \mathrm{MEM}, 15 \% \mathrm{FCS}$ supplemented with $10^{-8} \mathrm{M} \mathrm{1}$, and 25-dihydroxy vitamin D (Sigma-Aldrich). At day 7 of the culture, cells were fixed with $2 \%$ paraformaldehyde, washed with PBS, and incubated with a mixture of $2 \mathrm{mg} / \mathrm{ml}$ Naphtol AS-TR Phosphate (SigmaAldrich) and $5 \mathrm{mg} / \mathrm{ml}$ Fast Violet B Salt (Sigma-Aldrich) for $1 \mathrm{~h}$ at $40^{\circ} \mathrm{C}$. TRAP-expressing $\left(\right.$ TRAP $\left.^{+}\right)$cells were counted under a light microscope, and cells with $\geq 3$ nuclei were considered as multinucleated osteoclasts. For resorption pit assay, equal numbers of mature osteoclasts from spleen cell cultures were plated on dentine slices (provided by N. Takahashi, Matsumoto Dental University, Nagano, Japan) for 48 h, and resorption pits were stained with toluidine blue after cell removal (56).

Real-time RT-PCR. Total RNA was isolated from midshaft femoral cortical bone (4-mo-old males) or from cell cultures using TRI Reagent according to the manufacturer's instructions (Sigma-Aldrich). Samples were reverse transcribed, and $50 \mathrm{ng}$ of the cDNA (RNA equivalent) was amplified through RT-PCR using the SYBR Green PCR Master Mix (Applied Biosystems) on the MyIQ single-color real-time PCR detection system (BioRad Laboratories). The raw, background-subtracted fluorescence data provided in the MyIQ software were analyzed by the real-time PCR Miner program (57). The resulting PCR efficiency and fractional cycle number of the threshold $\left(C_{\mathrm{T}}\right)$ were used for transcript quantification. mRNA expression was normalized to L32 mRNA. PCR primer sequences were chosen from PrimerBank (58), unless otherwise stated (Table III), and were verified to span introns.

Statistical analysis. Phenotypic evaluation (morphometry, histomorphometry, $\mu \mathrm{CT}$, densitometry, and microradiography) data, as well as in vitro experiments, were assessed with the Mann-Whitney $U$ test or Student's $t$ test (stromal cell colony counts). RT-PCR results were analyzed by Student's $t$ test. Tail suspension experiments were analyzed by two-way ANOVA with post test.

The authors thank Dr. N. Takahashi for the generous gift of dentine slices, Dr. A. Gupta for help with BSP gene sequencing and the Laboratoire de Transgenèse, Service Commun de I'Université de Bordeaux II, especially P. Costet and U. Bhargava (Toronto), for the care of animals.

This work was funded by the Canadian Institutes of Health Research (FRN83704 to J.E. Aubin) and by the Institut National de la Santé et de la Recherche Médicale (INSERM) and the Centre National de la Recherche Scientifique (CNRS), through both basal funding to affiliated laboratories and a collective grant within the Ingénierie Tissulaire-Biomécanique-Biomatériaux (IT2B) INSERM/CNRS cooperative program (to L. Malaval, M.-H. Lafage-Proust, J. Amedee, and L. Vico).

The authors have no conflicting financial interests.

Submitted: 25 June 2007

Accepted: 3 April 2008

\section{REFERENCES}

1. Fisher, L.W., and N.S. Fedarko. 2003. Six genes expressed in bones and teeth encode the current members of the SIBLING family of proteins. Connect. Tissue Res. 44:33-40.
2. Alford, A.I., and K.D. Hankenson. 2006. Matricellular proteins: extracellular modulators of bone development, remodeling, and regeneration. Bone. 38:749-757.

3. Rowe, P.S., P.A. de Zoysa, R. Dong, H.R. Wang, K.E. White, M.J. Econs, and C.L. Oudet. 2000. MEPE, a new gene expressed in bone marrow and tumors causing osteomalacia. Genomics. 67:54-68.

4. MacDougall, M., D. Simmons, T.T. Gu, and J. Dong. 2002. MEPE/ OF45, a new dentin/bone matrix protein and candidate gene for dentin diseases mapping to chromosome 4q21. Connect. Tissue Res. 43: 320-330.

5. Kawasaki, K., and K.M. Weiss. 2006. Evolutionary genetics of vertebrate tissue mineralization: the origin and evolution of the secretory calcium-binding phosphoprotein family. J. Exp. Zoolog. B Mol. Dev. Evol. 306:295-316.

6. Ogbureke, K.U., and L.W. Fisher. 2004. Expression of SIBLINGs and their partner MMPs in salivary glands. J. Dent. Res. 83:664-670.

7. Ogbureke, K.U., and L.W. Fisher. 2005. Renal expression of SIBLING proteins and their partner matrix metalloproteinases (MMPs). Kidney Int. 68:155-166.

8. Sodek, J., B. Ganss, and M.D. McKee. 2000. Osteopontin. Crit. Rev. Oral Biol. Med. 11:279-303

9. Patarca, R., R.A. Saavedra, and H. Cantor. 1993. Molecular and cellular basis of genetic resistance to bacterial infection: the role of the early T-lymphocyte activation-1/osteopontin gene. Crit. Rev. Immunol. 13:225-246.

10. Ganss, B., R.H. Kim, and J. Sodek. 1999. Bone sialoprotein. Crit. Rev. Oral Biol. Med. 10:79-98.

11. Hunter, G.K., and H.A. Goldberg. 1994. Modulation of crystal formation by bone phosphoproteins: role of glutamic acid-rich sequence in the nucleation of hydroxyapatite by bone sialoprotein. Biochem. J. 302:175-179.

12. Boskey, A.L., M. Maresca, W. Ullrich, S.B. Doty, W.T. Butler, and C.W. Prince. 1993. Osteopontin-hydroxyapatite interactions in vitro: inhibition of hydroxyapatite formation and growth in a gelatin-gel. Bone Miner. 22:147-159.

13. Kubota, T., M. Yamauchi, J. Onozaki, S. Sato, Y. Suzuki, and J. Sodek. 1993. Influence of an intermittent compressive force on matrix protein expression by ROS $17 / 2.8$ cells, with selective stimulation of osteopontin. Arch. Oral Biol. 38:23-30.

14. Carvalho, R.S., A. Bumann, J.L. Schaffer, and L.C. Gerstenfeld. 2002. Predominant integrin ligands expressed by osteoblasts show preferential regulation in response to both cell adhesion and mechanical perturbation. J. Cell. Biochem. 84:497-508.

15. Ishijima, M., S.R. Rittling, T. Yamashita, K. Tsuji, H. Kurosawa, A. Nifuji, D.T. Denhardt, and M. Noda. 2001. Enhancement of osteoclastic bone resorption and suppression of osteoblastic bone formation in response to reduced mechanical stress do not occur in the absence of osteopontin. J. Exp. Med. 193:399-404.

16. Yoshitake, H., S.R. Rittling, D.T. Denhardt, and M. Noda. 1999. Osteopontin-deficient mice are resistant to ovariectomy-induced bone resorption. Proc. Natl. Acad. Sci. USA. 96:8156-8160.

17. Boivin, G., and P.J. Meunier. 2002. The degree of mineralization of bone tissue measured by computerized quantitative contact microradiography. Calcif. Tissue Int. 70:503-511.

18. Amblard, D., M.H. Lafage-Proust, A. Laib, T. Thomas, P. Ruegsegger, C. Alexandre, and L. Vico. 2003. Tail suspension induces bone loss in skeletally mature mice in the $\mathrm{C} 57 \mathrm{BL} / 6 \mathrm{~J}$ strain but not in the $\mathrm{C} 3 \mathrm{H} / \mathrm{HeJ}$ strain. J. Bone Miner. Res. 18:561-569.

19. Huq, N.L., K.J. Cross, M. Ung, and E.C. Reynolds. 2005. A review of protein structure and gene organisation for proteins associated with mineralised tissue and calcium phosphate stabilisation encoded on human chromosome 4. Arch. Oral Biol. 50:599-609.

20. Rittling, S.R., H.N. Matsumoto, M.D. McKee, A. Nanci, X.R. An, K.E. Novick, A.J. Kowalski, M. Noda, and D.T. Denhardt. 1998. Mice lacking osteopontin show normal development and bone structure but display altered osteoclast formation in vitro. J. Bone Miner. Res. 13:1101-1111.

21. Sreenath, T., T. Thyagarajan, B. Hall, G. Longenecker, R. D'Souza, S Hong, J.T. Wright, M. MacDougall, J. Sauk, and A.B. Kulkarni. 2003. 
Dentin sialophosphoprotein knockout mouse teeth display widened predentin zone and develop defective dentin mineralization similar to human dentinogenesis imperfecta type III. J. Biol. Chem. 278:24874-24880.

22. Gowen, L.C., D.N. Petersen, A.L. Mansolf, H. Qi, J.L. Stock, G.T. Tkalcevic, H.A. Simmons, D.T. Crawford, K.L. Chidsey-Frink, H.Z. $\mathrm{Ke}$, et al. 2003. Targeted disruption of the osteoblast/osteocyte factor 45 gene (OF45) results in increased bone formation and bone mass. J. Biol. Chem. 278:1998-2007.

23. Ling, Y., H.F. Rios, E.R. Myers, Y. Lu, J.Q. Feng, and A.L. Boskey. 2005. DMP1 depletion decreases bone mineralization in vivo: an FTIR imaging analysis. J. Bone Miner. Res. 20:2169-2177.

24. Feng, J.Q., L.M. Ward, S. Liu, Y. Lu, Y. Xie, B. Yuan, X. Yu, F. Rauch, S.I. Davis, S. Zhang, et al. 2006. Loss of DMP1 causes rickets and osteomalacia and identifies a role for osteocytes in mineral metabolism. Nat. Genet. 38:1310-1315.

25. Yang, W., S.E. Harris, P. Raw, J. Feng, and J. Gluhak-Heinrich. 2006. MEPE over-expression in osteocytes of Dmp1 null mice by activation of the PKA/CREB pathway. J. Bone Miner. Res. 21:S136.

26. Gajjeraman, S., K. Narayanan, J. Hao, C. Qin, and A. George. 2007. Matrix macromolecules in hard tissues control the nucleation and hierarchical assembly of hydroxyapatite. J. Biol. Chem. 282:1193-1204.

27. Harmey, D., K.A. Johnson, J. Zelken, N.P. Camacho, M.F. Hoylaerts, M. Noda, R. Terkeltaub, and J.L. Millan. 2006. Elevated skeletal osteopontin levels contribute to the hypophosphatasia phenotype in Akp2(-/-) mice. J. Bone Miner. Res. 21:1377-1386.

28. Boskey, A.L., L. Spevak, E. Paschalis, S.B. Doty, and M.D. McKee. 2002. Osteopontin deficiency increases mineral content and mineral crystallinity in mouse bone. Calcif. Tissue Int. 71:145-154.

29. Midura, R.J., A. Wang, D. Lovitch, D. Law, K. Powell, and J.P. Gorski. 2004. Bone acidic glycoprotein-75 delineates the extracellular sites of future bone sialoprotein accumulation and apatite nucleation in osteoblastic cultures. J. Biol. Chem. 279:25464-25473.

30. Gorski, J.P., A. Wang, D. Lovitch, D. Law, K. Powell, and R.J. Midura. 2004. Extracellular bone acidic glycoprotein-75 defines condensed mesenchyme regions to be mineralized and localizes with bone sialoprotein during intramembranous bone formation. J. Biol. Chem. 279:25455-25463

31. Fedarko, N.S., A. Jain, A. Karadag, and L.W. Fisher. 2004. Three small integrin binding ligand $\mathrm{N}$-linked glycoproteins (SIBLINGs) bind and activate specific matrix metalloproteinases. FASEB J. 18:734-736.

32. Oldberg, A., A. Franzen, and D. Heinegard. 1986. Cloning and sequence analysis of rat bone sialoprotein (osteopontin) cDNA reveals an Arg-Gly-Asp cell-binding sequence. Proc. Natl. Acad. Sci. USA. 83: 8819-8823.

33. Somerman, M.J., L.W. Fisher, R.A. Foster, and J.J. Sauk. 1988. Human bone sialoprotein I and II enhance fibroblast attachment in vitro. Calcif. Tissue Int. 43:50-53.

34. Oldberg, A., A. Franzen, D. Heinegard, M. Pierschbacher, and E. Ruoslahti. 1988. Identification of a bone sialoprotein receptor in osteosarcoma cells. J. Biol. Chem. 263:19433-19436.

35. Miyauchi, A., J. Alvarez, E.M. Greenfield, A. Teti, M. Grano, S. Colucci, A. Zambonin-Zallone, F.P. Ross, S.L. Teitelbaum, D. Cheresh, et al. 1991. Recognition of osteopontin and related peptides by an alpha $\mathrm{v}$ beta 3 integrin stimulates immediate cell signals in osteoclasts. J. Biol. Chem. 266:20369-20374.

36. Ross, F.P., J. Chappel, J.I. Alvarez, D. Sander, W.T. Butler, M.C. Farach-Carson, K.A. Mintz, P.G. Robey, S.L. Teitelbaum, and D.A. Cheresh. 1993. Interactions between the bone matrix proteins osteopontin and bone sialoprotein and the osteoclast integrin alpha $\mathrm{v}$ beta 3 potentiate bone resorption. J. Biol. Chem. 268:9901-9907.

37. Bellahcene, A., M.P. Merville, and V. Castronovo. 1994. Expression of bone sialoprotein, a bone matrix protein, in human breast cancer. Cancer Res. 54:2823-2826.

38. Bellahcene, A., S. Menard, R. Bufalino, L. Moreau, and V. Castronovo. 1996. Expression of bone sialoprotein in primary human breast cancer is associated with poor survival. Int. J. Cancer. 69:350-353.
39. Bellahcène, A., N. Maloujahmoum, L.W. Fisher, H. Pastorino, E. Tagliabue, S. Menard, and V. Castronovo. 1997. Expression of bone sialoprotein in human lung cancer. Calcif. Tissue Int. 61:183-188.

40. Rangaswami, H., A. Bulbule, and G.C. Kundu. 2006. Osteopontin: role in cell signaling and cancer progression. Trends Cell Biol. 16:79-87.

41. Bellahcene, A., K. Bonjean, B. Fohr, N.S. Fedarko, F.A. Robey, M.F. Young, L.W. Fisher, and V. Castronovo. 2000. Bone sialoprotein mediates human endothelial cell attachment and migration and promotes angiogenesis. Circ. Res. 86:885-891.

42. Zhou, H.Y., H. Takita, R. Fujisawa, M. Mizuno, and Y. Kuboki. 1995. Stimulation by bone sialoprotein of calcification in osteoblast-like MC3T3-E1 cells. Calcif. Tissue Int. 56:403-407.

43. Cooper, L.F., P.K. Yliheikkila, D.A. Felton, and S.W. Whitson. 1998 Spatiotemporal assessment of fetal bovine osteoblast culture differentiation indicates a role for BSP in promoting differentiation. J. Bone Miner. Res. 13:620-632.

44. Mizuno, M., T. Imai, R. Fujisawa, H. Tani, and Y. Kuboki. 2000 Bone sialoprotein (BSP) is a crucial factor for the expression of osteoblastic phenotypes of bone marrow cells cultured on type I collagen matrix. Calcif. Tissue Int. 66:388-396.

45. Wang, J., H.Y. Zhou, E. Salih, L. Xu, L. Wunderlich, X. Gu, J.G. Hofstaetter, M. Torres, and M.J. Glimcher. 2006. Site-specific in vivo calcification and osteogenesis stimulated by bone sialoprotein. Calcif. Tissue Int. 79:179-189.

46. Gordon, J.A., C.E. Tye, A.V. Sampaio, T.M. Underhill, G.K. Hunter, and H.A. Goldberg. 2007. Bone sialoprotein expression enhances osteoblast differentiation and matrix mineralization in vitro. Bone. 41: 462-473.

47. Raynal, C., P.D. Delmas, and C. Chenu. 1996. Bone sialoprotein stimulates in vitro bone resorption. Endocrinology. 137:2347-2354.

48. Valverde, P., Q. Tu, and J. Chen. 2005. BSP and RANKL induce osteoclastogenesis and bone resorption synergistically. J. Bone Miner. Res. 20:1669-1679.

49. Nakamura, I., T. Duong le, S.B. Rodan, and G.A. Rodan. 2007. Involvement of alpha(v)beta3 integrins in osteoclast function. J. Bone Miner. Metab. 25:337-344.

50. Chellaiah, M.A., N. Kizer, R. Biswas, U. Alvarez, J. StraussSchoenberger, L. Rifas, S.R. Rittling, D.T. Denhardt, and K.A. Hruska 2003. Osteopontin deficiency produces osteoclast dysfunction due to reduced CD44 surface expression. Mol. Biol. Cell. 14:173-189.

51. Nagy, A., J. Rossant, R. Nagy, W. Abramow-Newerly, and J.C. Roder. 1993. Derivation of completely cell culture-derived mice from early-passage embryonic stem cells. Proc. Natl. Acad. Sci. USA. 90:8424-8428.

52. Hogan, B.L., M. Blessing, G.E. Winnier, N. Suzuki, and C.M. Jones. 1994. Growth factors in development: the role of TGF-beta related polypeptide signalling molecules in embryogenesis. Dev. Suppl. 53-60.

53. David, V., N. Laroche, B. Boudignon, M.H. Lafage-Proust, C. Alexandre, P. Ruegsegger, and L. Vico. 2003. Noninvasive in vivo monitoring of bone architecture alterations in hindlimb-unloaded female rats using novel three-dimensional microcomputed tomography. J. Bone Miner. Res. 18:1622-1631.

54. Aubin, J.E. 1999. Osteoprogenitor cell frequency in rat bone marrow stromal populations: role for heterotypic cell-cell interactions in osteoblast differentiation. J. Cell. Biochem. 72:396-410.

55. Bonyadi, M., S.D. Waldman, D. Liu, J.E. Aubin, M.D. Grynpas, and W.L. Stanford. 2003. Mesenchymal progenitor self-renewal deficiency leads to age-dependent osteoporosis in Sca-1/Ly-6A null mice. Proc. Natl. Acad. Sci. USA. 100:5840-5845.

56. Solari, F., F. Flamant, Y. Cherel, M. Wyers, and P. Jurdic. 1996. The osteoclast generation: an in vitro and in vivo study with a genetically labelled avian monocytic cell line. J. Cell Sci. 109:1203-1213.

57. Zhao, S., and R.D. Fernald. 2005. Comprehensive algorithm for quantitative real-time polymerase chain reaction. J. Comput. Biol. 12: 1047-1064.

58. Wang, X., and B. Seed. 2003. A PCR primer bank for quantitative gene expression analysis. Nucleic Acids Res. 31:e154. 